\title{
Bacillus spp. Suşlarından Ksilanaz Enziminin Kısmi Saflaştırılması ve Karakterizasyonu
}

\author{
Hatice Aysun MERCIMEK TAKCI ${ }^{1 *}$, Gökhan SERTBAŞ ${ }^{1}$ \\ ${ }^{1}$ Kilis 7 Aralık Üniversitesi, Fen-Edebiyat Fakültesi, Moleküler Biyoloji ve Genetik Bölümü, Kilis, Türkiye
}

Geliş Tarihi: 23.09 .2019

*Sorumlu Yazar: mersimek@hotmail.com

Kabul Tarihi: 15.12 .2019

\section{$\ddot{O} \mathbf{z}$}

$\beta-1,4$ bağlı ksilopiranozil rezidülerinden oluşan ksilanın $\beta-1,4$ glikozidik bağlarını yıkan ksilanaz, başta kağıt ve kağıt hamuru endüstrileri olmak üzere tekstil, yem, firın ve biyoyakıt endüstrilerinde geniş potansiyel uygulamalara sahip endüstriyel bir enzimdir. Bu çalışmada, Kilis 7 Aralık Üniversitesi merkez kampüsü toprak örneğinden ksilanaz üretici Bacillus spp. suşlarının izolasyonu ve saflaştırılan ksilanazın çeşitli endüstrilerdeki uygulanabilirliği araştırılmıştır. Ksilan içeren sıvı fermantasyon ortamında geliştirilen Bacillus spp. suşundan elde edilen hücre içermeyen ham ksilanaz, amonyum sülfat ve alkol çöktürmesi ile kısmi olarak saflaştırılmıştır. En yüksek total ve spesifik enzim aktivitesi 723 $\mathrm{U} / \mathrm{L}$ ve $64.81 \mathrm{U} / \mathrm{mg}$ olarak ham enzim solüsyonunda saptanmıştır. Ksilanaz, optimum aktivitesini $90^{\circ} \mathrm{C}$ ve $\mathrm{pH} 10.6^{\prime}$ da göstermiştir. Enzimin $90^{\circ} \mathrm{C}$ sıcaklıkta 15 dakika ön inkübasyonu sonrası aktivitenin \%167'e kadar arttığı saptanmıştır. Karakterizasyon çalışmalarındaki en yüksek aktivitesi 2935 U/L olarak hesaplanmıştır. SDS-PAGE ve zimogram analizlerinde, kısmi saflaştırılmış hücre dışı ksilanaza ait yaklaşık $38.75 \mathrm{kDa}$ moleküler ağırlığında tek bir protein bandı gözlenmiştir.

Anahtar Kelimeler: Bacillus spp., karakterizasyon, kısmi saflaştırma, ksilan, ksilanaz.

\section{Partial Purification and Characterization of Xylanase Enzyme from Bacillus spp. Strains}

\begin{abstract}
Xylanase that cleaves $\beta$-1,4-glycosidic linkages of xylan composed of $\beta$-1,4-linked xylopyranosyl residues, is a industrial enzyme, have widespread potential applications in the textile, feed, beverage and biofuel industries, especially the paper and pulp industry. In this study, isolation of xylanase producer Bacillus spp. strains from soil sample from Kilis 7 Aralık University central campus and applicability of the purified xylanase in various industries were investigated. The cell-free crude xylanase obtained from Bacillus spp. strain developed in a liquid fermentation medium including xylan was partially purified by using ammonium sulfate and alcohol precipitation. The highest total and specific enzyme activities were detected as $723 \mathrm{U} / \mathrm{L}$ and $64.81 \mathrm{U} / \mathrm{mg}$ in cell-free crude xylanase solution. The optimum activity of xylanase was emerged at $90^{\circ} \mathrm{C}$ and $\mathrm{pH} 10.6$. After the pre-incubation of enzyme at $90^{\circ} \mathrm{C}$ for $15 \mathrm{~min}$, its activity was detected to increase up to $167 \%$. In characterization studies, the highest enzyme activity was calculated as $2935 \mathrm{U} / \mathrm{L}$. In SDS-PAGE and zymogram analyses, single protein band in $38.75 \mathrm{kDa}$ molecular weight belonging to the partially purified extracellular xylanase was observed.
\end{abstract}

Keywords: Bacillus spp., characterization, partially purification, xylan, xylanase. 


\section{Giriş}

Ksilan, hem sert ağaçlarda hem de yıllık bitkilerde en çok bulunan selülozik olmayan polisakkarittir ve tropikal bitki biyokütlesindeki toplam kuru ağırlığın \%20-35'ini oluşturmaktadır. Ksilanın, bitki duvar yapısında lignin ve diğer polisakkaritler arasında bir ara yüzey oluşturduğu düşünülmektedir. Lignin fenolik rezidüleri ile kovalent olarak bağlı ksilan molekülü pektin ve glukan gibi polisakkaritler ile etkileşime girmektedir. En basit formunda, ksilanlar, $\beta$-1,4-glikozit bağlarla bağlı D-ksiloz monomerlerini içeren lineer homopolimerlerdir (Motta ve ark., 2013). Kağıt üretiminde kağıt hamurunu ağartmak, kağıt hamurunun parlaklığını arttırmak, hayvan yemlerinin sindirilebilirliğini arttırmak ve meyve sularının berraklaştırılmasında ksilanazlar, ksilanın hidrolitik yıkımın katalizleyen enzimlerdir. Çeşitli bakteri türleri ve fungusları içeren mikroorganizmalar zengin ksilanaz kaynaklarıdır. Ksilanazların bu mikroorganizmalarca hücre dışı salgılanması düşük veya yüksek miktarda selülaz ile ilişkilendirilmektedir (Chakdar ve ark., 2016). Selülaz kağıt hamurunun kalitesini olumsuz olarak etkileyebileceğinden, kağıt hamuruna ksilanaz uygulanması selüloz içermeyen ksilanazların kullanımı ile mümkündür. Ksilanazın ağartma işleminde göze çarpan şekilde kullanılması, yüksek sıcaklık ve alkalin pH'da stabil olması ile mümkündür (Kamble ve Jadhav, 2012).

Heterojen ve karmaşık kimyasal yapısından dolayı bitki ksilanı, farklı özellikte ve aktivitede çeşitli hidrolitik enzimlerin birlikte aktivite göstermesi ile tamamen yıkıma uğratılabilmektedir (Şekil $1)$.

Ksilanolitik enzim sistemi, endoksilanaz (endo-1,4 $\beta$-ksilanaz, E.C.3.2.1.8), $\beta$-ksilozidaz (ksilan-1,4 $\beta$-ksilozidaz, E.C.3.2.1.37), $\alpha$-glukuronidaz (E.C.3.2.1.139), $\alpha$-arabinofuranozidaz ( $\alpha$-Larabinofuranozidaz, E.C.3.2.1.55) ve asetilksilan esteraz (E.C.3.1.1.72) enzimlerinden oluşmaktadır. Bu enzimler, ksilanı monomerlerine parçalamak için birlikte aktivite gösterirler (Motta ve ark., 2013). Ksilanazlar tek zincirli glikoproteinler olup, genel olarak moleküler ağırlıkları 6-80 kDa arasında değişmekte ve 40 ila $60^{\circ} \mathrm{C}$ sıcaklıklarda ve pH 4.5-6.5 arasında aktivite gösterirler (Butt ve ark., 2008).

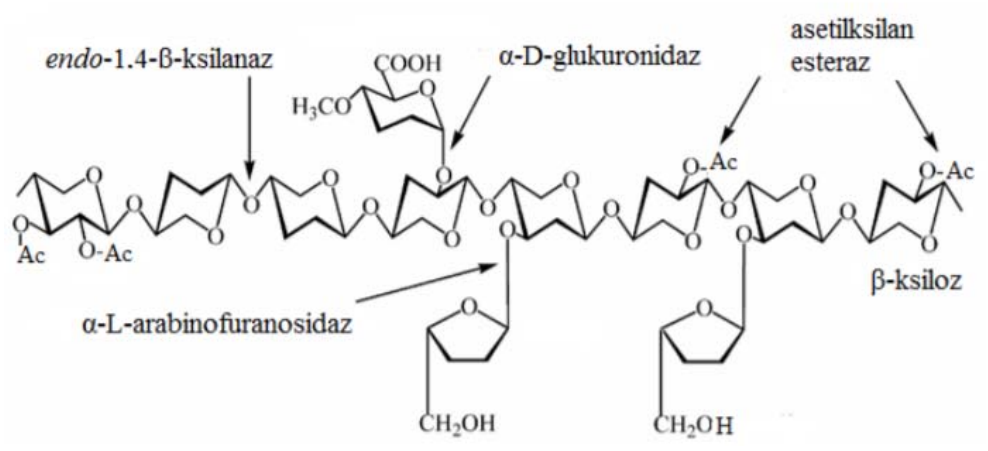

Şekil 1. Ksilanın hidrolizini katalizleyen ksilanolitik enzimler (Sarı, 2016). 
Ekmek üretiminde enzimler, hamur esnekliğini, işlenebilirliğini, stabilitesini ve kalitesini arttırmak amacıyla kullanılmaktadır. Proteaz, ksilanaz ve selülaz gibi enzimler doğrudan veya dolaylı olarak gluten ağının sağlamlığını geliştirerek ekmeğin kalitesini iyileştirir. Ksilanlar, su emme kabiliyeti ve gluten ile etkileşimlerinden ötürü ekmek kalitesinde önemli bir role sahiptir. Ksilanazlar hamurların, farklı kalitede unlara ve işleme parametrelerindeki değişimlere karşı daha toleranslı olmasını sağlar. Ayrıca hamurları yumuşatırlar, diğer bir deyişle kaplama iş gereksinimini azaltırlar ve pişmiş ekmeğin hacmini önemli derecede arttırırlar (Butt ve ark., 2008).

Ksilanazlar ve üretici mikroorganizmalar, atık yönetiminde, ksilanı yenilenebilir yakıtlara ve kimyasallara indirgemede ve gıda, tarımsal lif ve kağıt ile kağıt hamuru endüstrilerinde kullanım alanı bulmaktadır. Ksilanazların katalitik aktiviteleri sonucu üretilen oligosakkaritler, fonksiyonel gıda katkı maddeleri veya faydalı alternatif tatlandırıcılar olarak değerlendirilmektedir (Motta ve ark., 2013).

Ksilanolitik enzimler aynı zamanda kahve, bitki yağları ve nişasta özütü elde etmek için meyve suları ve şarapları berraklaştırmak, tarımsal silajın ve tahıl yeminin besleyici özelliklerini geliştirmek için kullanılmaktadır. Ksiloz, ksilobioz, ve ksilooligomerler gibi şekerler ksilanın enzimatik hidrolize ile hazırlanabilmektedir. Lignoselülozların fermente şekerlere biyolojik dönüşümü büyük bir ekonomik öneme sahiptir (Butt ve ark., 2008).

Çalışmamızda, ksilanaz üretici yabani tip Bacillus spp. suşlarının izolasyonu, sıvı fermantasyon ortamından hücre dışı enzim saflaştırılması ve karakterizasyonu amaçlanmıştır.

\section{Materyal ve Metot}

\subsection{Bacillus spp. izolasyonu}

Kilis 7 Aralık Üniversitesi kampüs çevresi toprağının üst yüzeyi temizlendikten sonra steril bir spatula ile yaklaşık $5 \mathrm{~cm}$ derinlikten 10 gram olacak şekilde toprak örnekleri alınmıştır. Alınan örnekler kullanılıncaya kadar $+4^{\circ} \mathrm{C}$ 'de cam steril şişelerde muhafaza edilmiş ve Bacillus spp. izolasyonu için materyal olarak değerlendirilmiştir. 1'er gr toprak örneği tartılarak, $9 \mathrm{~mL}$ steril fizyolojik tuzlu suda çözünmesi sağlanmıştır. Süspansiyon $65^{\circ} \mathrm{C}^{\prime}$ lik su banyosunda $30 \mathrm{dk}$. inkübe edilmiştir. Seri dilüsyonlar hazırlanmış ve $10^{-3}, 10^{-5}$ ve $10^{-8}$ seyreltmelerden $100 \mu \mathrm{L}$ alınıp nutrient agar besiyerine yayma preparasyon şeklinde inoküle edilmiştir. $24-48$ saat $37^{\circ} \mathrm{C}$ 'de inkübe edilen petri plaklarından seçilen izolatlar Gr boyanma karakterleri yönünden test edilmiştir. Gr boyama ve spor boyama karakteri açısından Bacillus spp. olduğu belirlenen suşlar enzim üretim çalışmalarında kullanılmak amacıyla muhafaza edilmiştir. Luria Bertani (LB) brothda $37^{\circ} \mathrm{C}$ 'de geliştirilmiş 1 gecelik taze kültürlerden örnek alınarak, toplam hacmin \%30’u steril gliserol olan steril eppendorf tüplerine 
eklenip $-20^{\circ} \mathrm{C}$ 'de saklanmıştır. Ayrıca, suşlar Nutrient Agar (NA) içeren yatık agar tüplerine her 6 ayda bir pasajlama yapılarak stoklanmıştır.

\subsection{Ksilanaz üretici Bacillus spp.'lerin belirlenmesi}

Suşlar 28 g NA ve 20 g ksilan içeren besiyerine nokta ekim şeklinde inoküle edilmiştir (Mahilrajan ve ark., 2012). $37^{\circ} \mathrm{C}$ 'de 24 saat inkübasyonu takiben plaklar kongo kırmızısı ayracı eklenerek $30 \mathrm{dk}$. oda sıcaklığında inkübe edilmiştir. Kongo kırmızısı ayracı dökülmüş ve 1 M'lık $\mathrm{NaCl}$ çözeltisi ile $5 \mathrm{dk}$. yıkanan petri plaklarında ksilanaz üretici bakterilerin izolasyonu için kolonilerin etrafında şeffaf zonların varlığı incelenmiştir. Şeffaf zon gösteren suşlar NA içeren tüplerde stoklanarak, ksilanaz aktivite taraması için $5 \mathrm{~g} \mathrm{NaCl}, 5 \mathrm{~g}$ maya özütü, $5 \mathrm{~g}$ tripton, $5 \mathrm{~g}$ ksilan ve 0.125-0.150 kongo kırmızısı içeren besi ortamına inoküle edilmiştir. $37^{\circ} \mathrm{C}$ de $24-48$ saatlik inkübasyon süresince kültürlerde kırmızıdan sarıya renk değişimleri test edilmiştir (İnce, 2006).

\subsection{Sıvı fermantasyon ortamında ksilanaz üretimi}

Ksilanaz üretici izolatların taranması sırasında etraflarında şeffaf zon ve sıvı besiyerinde renk değişimi gözlenen suşlar, enzim üretim için $5 \mathrm{~mL} \mathrm{sıvı} \mathrm{fermantasyon} \mathrm{ortamı}\left(2 \mathrm{~g}\left(\mathrm{NH}_{4}\right)_{2} \mathrm{SO}_{4}, 2.5 \mathrm{~g}\right.$ $\mathrm{K}_{2} \mathrm{HPO}_{4}, 1 \mathrm{~g} \mathrm{KH} \mathrm{PO}_{4}, 0.1 \mathrm{~g} \mathrm{NaCl}, 0.005 \mathrm{~g} \mathrm{MgCl}_{2} .6 \mathrm{H}_{2} \mathrm{O}, 0.005 \mathrm{~g} \mathrm{CaCl}_{2} .2 \mathrm{H}_{2} \mathrm{O}, 0.005 \mathrm{~g} \mathrm{FeCl}, 2.5 \mathrm{~g}$ maya özütü, $2 \mathrm{~g}$ pepton ve $20 \mathrm{~g}$ ksilan) bulunan tüplere inoküle edilerek $37^{\circ} \mathrm{C}$ 'de 24 saat $180 \mathrm{rpm}$ 'de çalkalamalı koşullarda ön inkübasyona bırakılmıştır. İnkübasyonu takiben, $95 \mathrm{~mL}$ aynı besiyeri içeren $500 \mathrm{~mL}$ 'lik burgulu kapaklı şişelere $5 \mathrm{~mL}$ 'lik kültür aktarılarak $37^{\circ} \mathrm{C}$ 'de $180 \mathrm{rpm}$ çalkalama hızında 24-48 saat inkübe edilmiştir (Mahilrajan ve ark., 2012).

İnkübasyonu takiben kültür, steril falkon tüplere alınarak $5500 \mathrm{rpm}$ 'de $+4^{\circ} \mathrm{C}$ 'de $20 \mathrm{dk}$. santrifüj edilmiştir. Santrifüjleme sonrasında hücre içermeyen süpernatant steril falkon tüplerine aktarılarak ham enzim solüsyonu olarak değerlendirilmiştir.

Alkol presipitasyonu için, süpernatant \%96'l1k soğuk etanol ile toplam hacim $50 \mathrm{~mL}$ olacak şekilde 1:9 oranında karıştırılarak 1 gece $-20^{\circ} \mathrm{C}$ 'de bekletilmiştir. Alkol süspansiyonu 5500'rpm de $+4^{\circ} \mathrm{C}$ 'de 30 dak santrifüj edildikten sonra pellet halinde konsantre edilmiş enzim $0.2 \mathrm{M}$ Na-fosfat tamponunda $(\mathrm{pH} 7.0)$ çözülerek aktivite analizlerinde kullanılmak üzere $+4^{\circ} \mathrm{C}$ 'de saklanmıştır.

Tuz çöktürülmesi için susuz son hacim \%70-80 olacak şekilde amonyum sülfat kullanılmıştır. Ham enzim solüsyonuna yavaş yavaş eklenen amonyum sülfat tamamen çözündükten sonra $4^{\circ} \mathrm{C}$ 'de 24 saat manyetik karıştırıcıda karıştırılarak, proteinlerin çökmesi sağlanmıştır. Karışım $4^{\circ} \mathrm{C}$ 'de, 5500 rpm'de 20 dakika santrifüj edilerek elde edilen pellet, 0,2 M Na-fosfat tamponu (pH 7.0) içerisinde çözdürülmüştür. Ortamdaki amonyum sülfat tuzunun uzaklaştırmak için aktifleştirilmiş diyaz 
tüplerine alınan süspansiyon, diyaliz tamponu birer saat aralıklarla değiştirilerek $+4^{\circ} \mathrm{C}$ 'de aynı tampon çözeltiye karşı 24 saat diyaliz edilmiştir. Diyaliz sonrası tüp içerisindeki süspansiyon aktivite tayininde kullanılmak üzere $+4^{\circ} \mathrm{C}^{\prime}$ de saklanmıştır.

\title{
2.4 Hücre dışı ksilanaz aktivite tayini
}

Ham enzim preparatının $0.5 \mathrm{~mL}$ 'si $0.5 \mathrm{~mL}$ substrat ile karıştırıldıktan sonra $60^{\circ} \mathrm{C}$ 'de $4 \mathrm{dk}$. bekletilmiştir. Karışıma $1 \mathrm{~mL}$ 3,5-Dinitrosalisilik asit (DNS) çözeltisi ilave edilerek reaksiyon durdurulmuş ve kaynar su banyosunda $5 \mathrm{dk}$. bekletilmiştir. Daha sonra tüpler soğuk su banyosunda soğutulmuş ve $5 \mathrm{~mL}$ saf su ilavesini takiben örneklerin absorbansı $540 \mathrm{~nm}$ dalga boyunda spektrofotometrede köre karşı ölçülmüştür (İnce, 2006). Bu yöntem süpernatant, alkol presipitasyonu ve tuz çöktürme ile elde edilen tüm enzim preparatları için uygulanmıştır. 1 ünite (U) ksilanaz aktivitesi; optimal koşullar altında, 1 dakikada substratın (ksilan) hidrolizi ile $\mu$ mol cinsinden indirgen şekerin açığa çıkması için gerekli enzim miktarı olarak tanımlanmıştır (Silva ve ark., 2005). Aşağıdaki formüle göre aktivite hesabı yapılmıştır. Enzim preparatlarındaki protein miktarları Lowry ve arkadaşları (1951) tarafından bildirilen metoda göre yapılmıştır.

\author{
Aktivite hesabı: $\mathrm{W}^{*} \mathrm{~V} *$ Seyreltme faktörü/VE*T \\ W: Açığa çıkan ksiloz miktarı (OD540/ Standart grafikten elde edilen eğim) \\ VE: Enzim hacmi \\ V: Reaksiyon çözeltisi hacmi \\ t: Reaksiyon süresi
}

\subsection{Enzim karakterizasyonu}

Kısmi saflaştırma yöntemi ile elde edilen enzimin optimum aktivite gösterdiği pH değerinin saptanması için hazırlamış olduğumuz Sitrat (pH 3.0-5.8), Glisin (pH 2.4- 2.8), Tris-HCI (pH 7.49.0), Sitrat fosfat ( $\mathrm{pH}$ 6.2-6.6), Fosfat ( $\mathrm{pH}$ 7.0) ve Karbonat bikarbonat ( $\mathrm{pH}$ 9.4-10.6) tamponlar1 kullanılmıştır. Farklı pH değerlerindeki tampon içerisinde \%1'lik (w/v) ksilan substrat çözeltisi hazırlanarak aktivite analizlerinde belirtilen tayin metoduyla aktivite belirlenmiştir. En yüksek aktivitenin hesaplandığı $\mathrm{pH}$ değerindeki tamponda hazırlanmış substrat çözeltisi ile enzim, $20-120^{\circ} \mathrm{C}$ arasındaki sıcaklıklarda inkübe edilmiştir. Optimum sıcaklığın saptanması için $20-80^{\circ} \mathrm{C}$ aralığındaki sıcaklıkların inkübasyonu için su banyosu, $90^{\circ} \mathrm{C}-120^{\circ} \mathrm{C}$ aralığındaki sıcaklıklar için de yağ banyosu kullanılmıştır. Termal stabilitesinin saptanması için optimum sıcaklığın belirlendiği sıcaklıkta 0-30 dk. arasında enzim ön inkübasyona bırakılmıştır. Ön inkübasyonu takiben optimum aktivitenin 
gerçekleştiği $\mathrm{pH}$ değerinde hazırlanmış substrat ve enzim karıştırılarak optimum aktivitenin belirlendiği sıcaklık değerinde aktivite analizi uygulanmıştır. Laemmli (1970) tarafından bildirilen yöntem esas alınarak Sodyum dodesil sülfat poliakrilamid jel elektroforezi (SDS-PAGE) analizleri ile ksilanazın moleküler ağırlığı belirlenmiştir.

SDS-PAGE jelinde enzim aktivasyonunun belirlenmesi için uygulanan zimogram analizi, elektroforez sonlandırılmasını takiben protein bantlarının boyanması prosesi yerine, jelde moleküler ağırlıkların göre ayrılmış ve denatüre edilmiş proteinlerin renatürasyonu temeline göre belirlenmiştir. Renatürasyon çözeltileri kullanılarak gerçekleştirilen SDS'nin uzaklaştırılması için; jel öncelikle solüsyon 1'de (10 mM Tris, $5 \mathrm{mM} \beta$-Merkaptoetanol ve \%20 izopropanol, pH 7.5) 1 saat (50 rpm), solüsyon 2'de (50 mM Tris, $5 \mathrm{mM} \beta$-Merkaptoetanol ve $1 \mathrm{mM}$ EDTA, pH 7.5) bir gece $+4^{\circ} \mathrm{C}$ 'de bekletilir ve solüsyon 3'te (50 mM sodyum fosfat tamponu, $\mathrm{pH}$ 6.8) inkübasyona birakilır. Renatürasyon işleminden sonra, jel enzimin optimum aktivite gösterdiği sicaklıkta ksilan içeren çözeltide 6 saat inkübe edilir. Ksilanazın aktivasyon zonlarının belirlenmesi için \%1'lik kongo kırmızısı içerisinde jel, $30 \mathrm{dk}$. boyanır. $1 \mathrm{M} \mathrm{NaCl}$ çözeltisi kullanarak $15 \mathrm{dk}$. fazla boyanın geri alınması gerçekleştirilir ve sarı zonlar, enzimin aktivite gösterdiği bölgeler olarak karakterize edilir (Aygan, 2008).

\section{Bulgular ve Tartışma}

Kilis 7 Aralık Üniversitesi merkez kampüsünden alınan toprak örneklerinden 42 adet Bacillus spp. izole edilmiştir. Kolonilerin etrafındaki şeffaf zon gösteren 29 suşun ksilanaz üreticisi olduğu belirlenmiştir (Şekil 2).

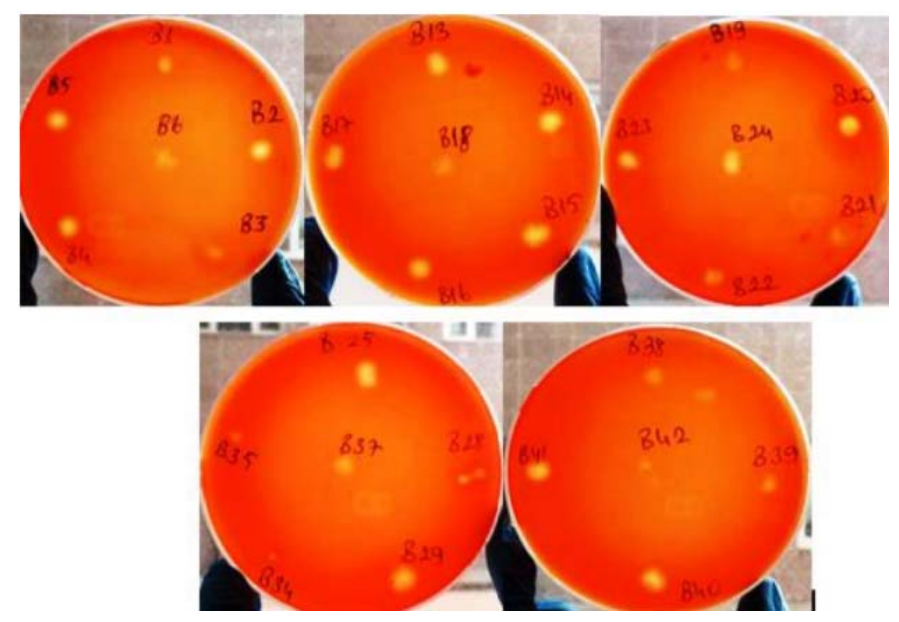

Şekil 2. Ksilan içeren katı besiyerinde suşların ksilanaz aktivitesi 
Agar ortamında seçilen bu suşlar, ksilanaz kültür taraması için kongo kırmızısı içeren sıvı besiyerine inoküle edilmiştir. İnkübasyonu takiben sıvı besi ortamındaki kırmızıdan sarıya renk değişimi takip edilmiştir. Buna göre 29 adet suşdan sıvı fermantasyon ortamında sadece 3 adet suşun ksilanaz aktivitesi gösterdiği saptanmıştır. Bu suşların B28, B34 ve B35 kodlu suşlar olduğu saptanmıştır (Şekil 3).

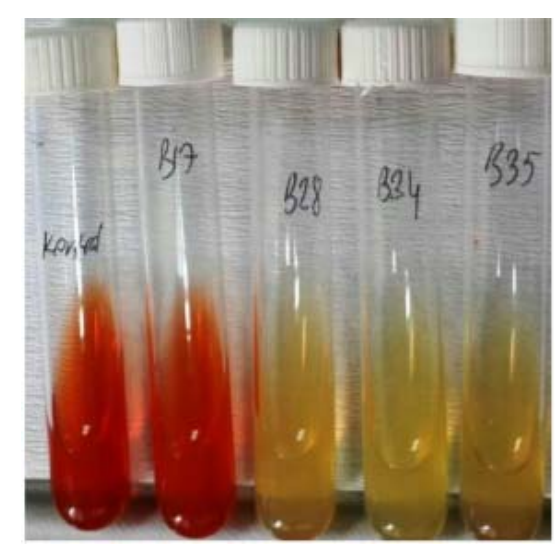

Şekil 3. Suşların sıvı besiyerinde renk değişimine dayalı ksilanaz aktivitesi

B28, B34 ve B35 kodlu suşların hücre dışı enzim aktivitesi belirlenmiş ve sırasıyla 552 U/L, $723 \mathrm{U} / \mathrm{L}$ ve $479 \mathrm{U} / \mathrm{L}$ şeklinde aktivite gösterdikleri saptanmıştır. Elde edilen sonuçlar değerlendirildiğinde enzim çalışmaları için B34 suşu ile devam edilmiştir. B34 suşuna ait ksilanaz aktivite sonuçları Tablo 1'de verilmiştir. Tamariz-Angeles ve arkadaşları (2014), Peru'dan izole ettikleri 8 adet termofilik bakteri türünden ksilanaz enzimini saflaştırmış ve en yüksek enzim aktivitesinin B. licheniformis IHB2 517 suşunda (517 U/L) olduğunu saptamışlardır.

Kalim ve Nazish (2016), optimize ettikleri kültür koşullarında geliştirdikleri B.pumilus ve B. safensis'den saflaştırdıkları ksilanazların spesifik aktivitelerini sırasıyla, $388.82 \mathrm{U} / \mathrm{mg}$ ve 385.26 U/mg olarak saptamışlardır. Zambare ve arkadaşları (2011) ise ksilan ile zenginleştirdikleri bahçe atıklarından izole ettikleri bakteriyel suşlardan saflaştırdıkları ksilanaz için spesifik aktiviteyi 2.09 $\mathrm{U} / \mathrm{mg}$ olarak saptamıştır.

Optimize edilmeyen kültür koşullarında çalışmamızda elde edilen en yüksek spesifik aktivite $64.81 \mathrm{U} / \mathrm{mg}$ olmuştur. 
Tablo 1. B34 suşundan elde edilen ksilanaz enzim preparatlarının total ve spesifik aktivitesi

\begin{tabular}{l|c|c|c|c|c}
\hline \multicolumn{1}{c|}{ Örnek } & $\begin{array}{c}\text { Total aktivite } \\
(\mathrm{U})\end{array}$ & $\begin{array}{c}\text { Total protein } \\
\text { miktar1 } \\
(\mathrm{mg} / \mathrm{mL})\end{array}$ & $\begin{array}{c}\text { Spesifik } \\
\text { aktivite } \\
(\mathrm{U} / \mathrm{mg})\end{array}$ & \% Verim & $\begin{array}{c}\text { Saflaştırma } \\
\text { katsayısı }\end{array}$ \\
\hline Ham enzim & 70 & 1.08 & 64.81 & 100 & 1 \\
\hline $\begin{array}{l}\text { Alkol } \\
\text { presipitasyonu }\end{array}$ & 10.5 & 0.44 & 23.86 & 15 & 0.37 \\
\hline $\begin{array}{l}\text { Amonyum sülfat } \\
\text { presipitasyonu }\end{array}$ & 0.6 & 0.35 & 1.714 & 0.86 & 0.026 \\
\hline
\end{tabular}

$\mathrm{Bu}$ aktivite sonuçlarına göre hücre kültürlerinin santrifüjlenmesi ile elde edilen hücre serbest ham enzim preparatının total aktivitesinin (70 U), alkol ve amonyum sülfat presipitasyonu ile elde edilen preparata oranla (10.5 ve $0.6 \mathrm{U})$ daha yüksek olduğu belirlenmiştir. Preparatlardaki total protein miktarları incelendiğinde, ham enzim preparatındaki protein miktarının $(1.08 \mathrm{mg} / \mathrm{mL})$ diğer preparatlara karşın, daha yüksek olduğu saptanmıştır. Saflaştırma basamaklarında enzimin saflığı arttıkça spesifik aktivitenin de artması gerekmektedir. Ancak uygulanan saflaştırma yöntemleri sonucunda spesifik aktivitenin azaldığı gözlenmektedir. Alkol presipitasyonu ve amonyum sülfat çöktürmesi sonucu elde edilen enzimin yeterince saf olmadığ gözlenmiş ve karakterizasyon çalışmalarına ham enzim preparatı ile devam edilmiştir.

Çalışmamızda B34 suşundan elde edilen hücre dışı ksilanazın saptanabilen en yüksek aktivitesi $\mathrm{pH}$ 10.6' da belirlenmiştir (Şekil 4). Bu pH aralığındaki enzim aktivitesi ise $1001 \mathrm{U} / \mathrm{L}$ olarak hesaplanmıştır. Literatür kaynaklarında da belirtildiği gibi, bakteriyel ksilanazların mantarlara göre en önemli avantajları, bakteri ksilanazlarının optimum $\mathrm{pH}$ değerlerinin nötral veya alkali aralıkta olmasıdır (Chakdar ve ark., 2016). Şekil 4’te görüldüğü gibi B34 suşundan elde edilen ksilanazın nötral ve alkali pH'larda yüksek aktiviteye sahip olduğu, ancak asidik pH'larda da aktivasyonunu sürdürdüğü gözlenmektedir. nötral pH'ya kadar en yüksek asidik aktivite pH 6.6' da 465 U/L olarak hesaplanmıştır. Ksilanazın pH 2.4-2.8 aralığında ortalama \%40.83 aktiviteden; pH 3.0-5.8 aralığında ortalamanın \%52.1'e kadar yükseldiği saptanmıştır. Analizlerinin sürdürüldüğü pH değerinin nötrale yaklaşmasıyla (6.2-6.6), enzimin ortalama aktivitesinin \%64.2'ye kadar arttı̆g ve pH 7'den 10.6'ya kadar ki ortalama aktivite ise \%74.23 olarak belirlenmiştir. B34 suşundan elde edilen hücre diş1 enzimin en yüksek aktivitesini pH 10.6'da gösterdiği ve bununla birlikte, $\mathrm{pH} 9.8$ ve 10.2'de de aktivitesini \%84 ve 85 koruduğu saptanmıştır. Bu sonuçlara dayanarak analiz edilen pH değerlerinde, ksilanazın alkali çözücülerde hazırlanmış substrat çözeltilerinde maksimum aktivite gösterdiği söylenebilmektedir. Alkali koşullardaki enzim stabilitesi amino asit rezidülerinin yüklenmesi ile karakterize edilmektedir. 


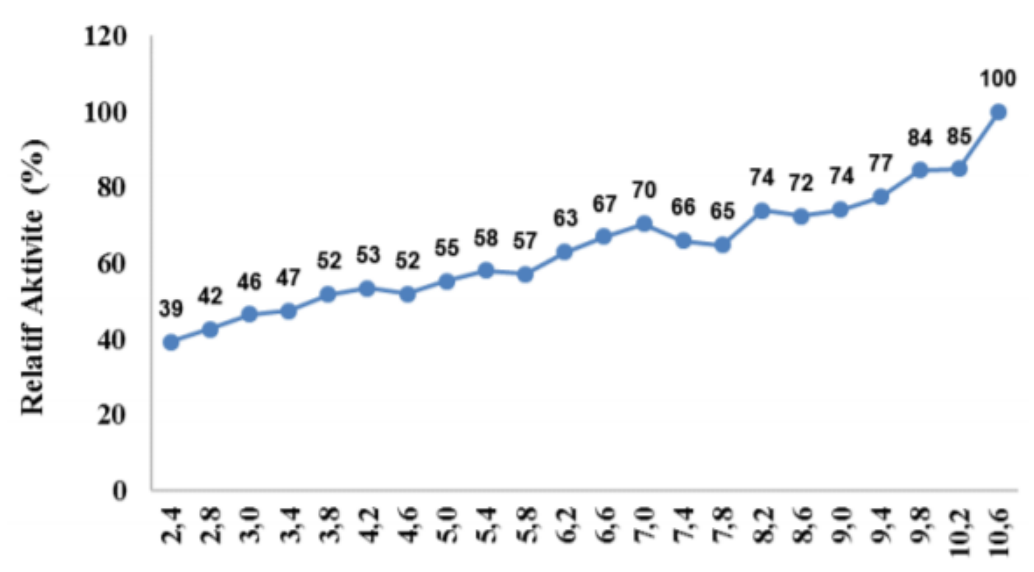

Şekil 4. Hücre dışı ksilanazın optimum aktivite gösterdiği pH aralıkları

Duarte ve arkadaşları (2000), B. pumilus'un dört farklı suşu ile çalışmış olup, suş 13a'nın optimum aktivitesini pH 9.0'da; 52, 514, ve 4a suşlarının ise pH 8.0'de gösterdiğini saptamışlardır. Hiremath ve Patil, (2013) Bidarın farklı bölgelerinden izole edilen $B$. suşlarından ksilanaz üretimi ve karakterizasyonu çalışmalarında, saflaştırılan enzimin en yükssek aktivitesini $\mathrm{pH}>10$ 'nun üzerinde belirlemişlerdir. Irfan ve arkadaşları (2016), optimize kültür koşullarında en yüksek enzim üretimini B. subtilis BS04 ve B.megaterium BM07 suşlarının her ikisi için de pH 8.0' da belirlerken, saflaştırılan ksilanaz enziminin en yüksek aktivitesi sirasıyla, $\mathrm{pH} 5.0$ ve 5.5 'te belirlenmiştir. Güncel kaynaklardan elde edilen bu veriler doğrultusunda pek çok faklı Bacillus spp.'den, hatta türlere ait farklı suşlardan saflaştırılan ksilanazların en yüksek aktivitelerini pH 5.0'dan pH 10.0'1n üzerindeki aralıkta gösterdikleri gözlenmektedir.

Bacillus spp.'den hücre dışı ksilanaz enziminin optimum aktivite gösterdiği sıcaklık değeri $90^{\circ} \mathrm{C}$ olarak belirlenmiştir (Şekil 5). Bu sicaklıkta hesaplanan enzim aktivitesi ise $1758 \mathrm{U} / \mathrm{L}$ olarak hesaplanmıştır. Çalışmamızın sonuçlarını destekler nitelikte, bakteriyel ksilanaza ait literatür incelemelerinde $65-90^{\circ} \mathrm{C}$ sicaklık aralığında en yüksek aktivitenin gözlendiği rapor edilmiştir (Chakdar ve ark., 2016). En düşük aktivite $20^{\circ} \mathrm{C}$ 'de gözlenmiş olup, $249 \mathrm{U} / \mathrm{L}$ olarak belirlenmiştir. 30-60 ${ }^{\circ} \mathrm{C}$ sıcaklık aralığında aktivitenin dereceli olarak arttığı gözlenmiş olup, ortalama aktivite \%62.14 olarak belirlenmiştir. $80^{\circ} \mathrm{C}$ 'de tekrar aktivitenin arttığ (\%77) ve en yüksek aktivite gösterdiği $90^{\circ} \mathrm{C}$ 'yi takiben uygulanan sıcaklıklarda aktivitenin ortalama \%66'ya kadar azaldığı tespit edilmiştir. Enzimin aktivitesini geniş bir sıcaklık aralığında $\left(40-110^{\circ} \mathrm{C}\right)$ kayda değer şekilde sürdürdüğü tespit edilmiştir. Tüm sıcaklık değerleri incelendiğinde ise, ortalama \%63.68 aktivite elde edilmiştir.

Sharma ve arkadaşları (2011), Bacillus sp.'den elde ettikleri ksilanaz enzimin aktivitesi üzerinde sıcaklık etkisini incelemişlerdir. $30-80^{\circ} \mathrm{C}$ aralığında sürdürülen çalışmada en yüksek aktivite $55^{\circ} \mathrm{C}$ 'de belirlenmiş olup, $70^{\circ} \mathrm{C}$ 'de aktivitenin yalnızca $\% 15$ kaldığg 1 ve $80^{\circ} \mathrm{C}$ 'de aktivite görülmediği rapor edilmiştir. Enzimin $50-60^{\circ} \mathrm{C}$ aralığında da yüksek aktiviteler gösterdiği tespit edilmiştir. Diğer 
bir çalışmada ise, Mittal ve arkadaşları (2012), Bacillus sp. KS09 suşundan elde ettikleri ksilanazın geniş sıcaklık aralığında aktivitesini sürdürdüğünü ancak en yüksek aktiviteye $50^{\circ} \mathrm{C}$ 'de sahip olduğunu belirlemişlerdir. Çalışmamızda mezofilik özellik taşıyan yabani tip Bacillus spp.'den saflaştırılan ksilanazın, $90^{\circ} \mathrm{C}$ 'de en yüksek aktivitesini gösterdiği gözlenmiştir. Çalışmamızı destekler nitelikte Cordeiro ve arkadaşları (2002), B. caldoxylolyticus ve Bacillus AK1 suşu ile ilişkili yabani tip Bacillus sp.'den saflaştırılan ksilanaz enziminin aktivite analizleri $30-100^{\circ} \mathrm{C}$ aralığında sürdürülmüş ve enzimin en yüksek aktivitesinin $90^{\circ} \mathrm{C}$ olduğu saptanmıştır.

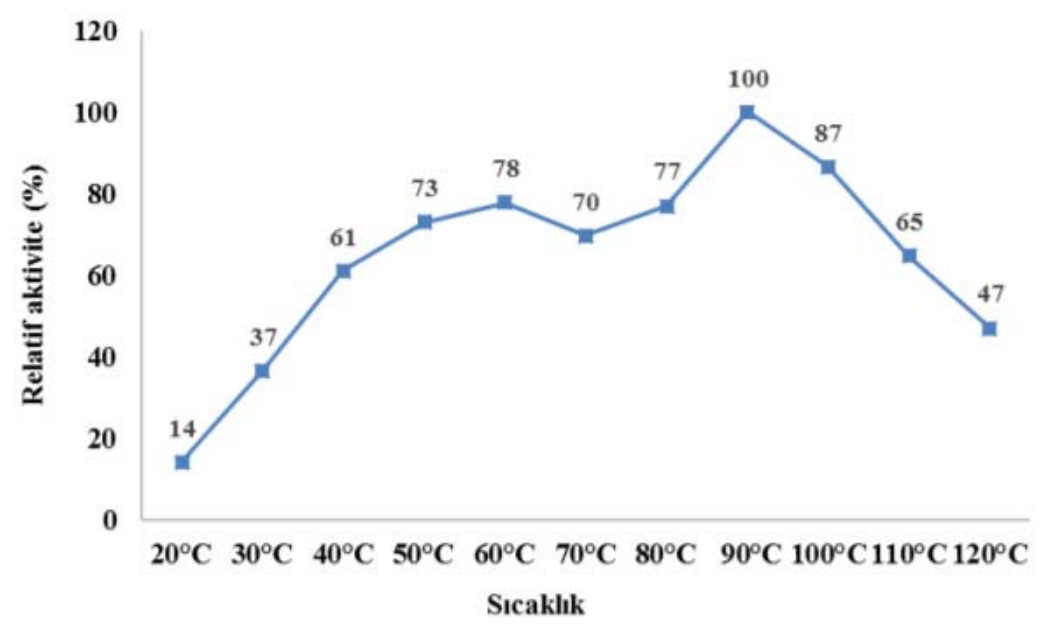

Şekil 5. Hücre dışı ksilanazın optimum aktivite gösterdiği sıcaklık değerleri

B34 suşundan elde edilen ham enzimin aktivitesini koruduğu termal stabilitenin belirlenmesi için, enzimin optimum aktivite gösterdiği $90^{\circ} \mathrm{C}$ sıcaklıkta $0,5,10,15,20,25$ ve 30 dakika ön inkübasyona tabii tutularak, optimum aktivite gösterdiği $\mathrm{pH}$ 10.6'daki karbonat-bikarbonat tamponunda hazırlanmış substrat çözeltisi ile aktivite analizleri gerçekleştirilmiştir. Buna göre elde edilen sonuçlar kalan rölatif enzim aktivitesi olarak Şekil 6' da gösterilmiştir. Enzimin ilk 5 dakikalık ön inkübasyonu takiben aktivitesinde \%32'lik bir azalma gözlenirken, inkübasyon süresinin artmasını takiben 0. dakikaya göre sırasıyla 10 ve 15 dakikalık ön inkübasyonla aktivitede, sırasıyla \%13 ve 67 artış kaydedilmiştir. En yüksek aktivitenin gözlendiği 15 dakikalık ön inkübasyonda hesaplanan enzim aktivitesi $2935 \mathrm{U} / \mathrm{L}$ 'dir.

Bir enzimin stabilitesi aktif yapısal konformasyonunu koruması olarak tanımlanır. Özellikle sıcaklık artışı gibi koşullarda enzimin aktif konformasyonunu koruyan temel kuvvetler hidrojen bağları ve hidrofobik etkilerdir. Bu stabilize etkileşimleri tipik olarak 5-10 $\mathrm{kcal} \mathrm{mol}^{-1} \mathrm{kadar}$ az etkileyici koşullardan daha ağır basmaktadır. Bu denge bir proteinin serbest enerjisi olarak bilinmektedir. Serbest enerjideki artışlar, tuz veya disulfit köprüleri, iyon eşleşme ve özellikle aktif bölgedeki aromatik rezidüler arasındaki etkileşimlerde artışlar gibi stabilize edici özelliklere aracılık etmektedir (Yeoman ve ark., 2010). Paës ve O’Donohue (2006) tarafindan Thermobacillus 
xylanilyticus'den saflaştırılan ksilanazın aktivitesinde termal stabilite çalışmaları sırasında enzimin yarılanma ömrünün $\left(180\right.$ dak. $\left.70^{\circ} \mathrm{C}\right) 10$ kat arttığı kaydedilmiştir. Bu artış disülfit köprülerin yapıya girmesi ile ilişkilendirilmiş ve spesifik aktivitenin iki katına çıktığı rapor edilmiştir.

İnkübasyonun 20. dakikasında ise ilk aktiviteye göre \%28 artma gözlense de 15. dakikada belirlenen en yüksek aktiviteye kıyasla \%39 azalma belirlenmiştir. 25 ve 30 dakikalık ön inkübasyon sürecinde enzimin aktivitesinde dereceli düşüş gözlense de, \%79 ve 52 oranında aktivitenin korunduğu saptanmıştır. B34 suşundan elde edilen hücre dışı ksilanaz enziminin en düşük aktivitesi 30 dakikalık inkübasyon süreci sonunda kaydedilmiş olup, aktivitenin \%50'sinden fazlasının korunduğu gözlenmektedir. $\mathrm{Bu}$ sonuçlara göre söz konusu enzimin inkübasyon sürelerinde termostabilitesini yüksek oranda koruduğu ve ilk aktiviteye göre artışın 10, 15 ve 20. dakikalardaki ön inkübasyon sonucu belirlendiği ortaya konmuştur. Bu sonuçlara göre B34 suşundan elde edilen hücre dışı ksilanazın termostabil bir enzim olduğu söylenebilmektedir.

Abo-State ve arkadaşları (2013), tarımsal atıklardan izole ettikleri iki Bacillus sp.'den (MAM29 ve MAM-38) saflaştırdıkları ksilanaz enziminin 60,70 ve $80^{\circ} \mathrm{C}^{\prime}$ lerde stabilitesini koruduğunu belirlemişlerdir. MAM-29 izolatından elde edilen ksilanazın $80^{\circ} \mathrm{C}$ 'de sürdürülen termostabilite çalışmalarında 60 dakikalık inkübasyon süresince aktivitesinin \%99'unu; MAM-38 ksilanazın ise \%98'ini koruduğu rapor edilmiştir. Diğer bir çalışmada ise Cordeiro ve arkadaşları (2002), yabani tip Bacillus sp.'in ürettiği ksilanazın $30-50^{\circ} \mathrm{C}$ 'lerde 2 saatlik inkübasyon sonunda aktivitesini \%100 koruduğunu; 60,70 ve $100^{\circ} \mathrm{C}^{\prime}$ lerde ise orijinal aktivitenin sırasıyla \%11, 12 ve 29 oranında azaldığını bildirmişlerdir.

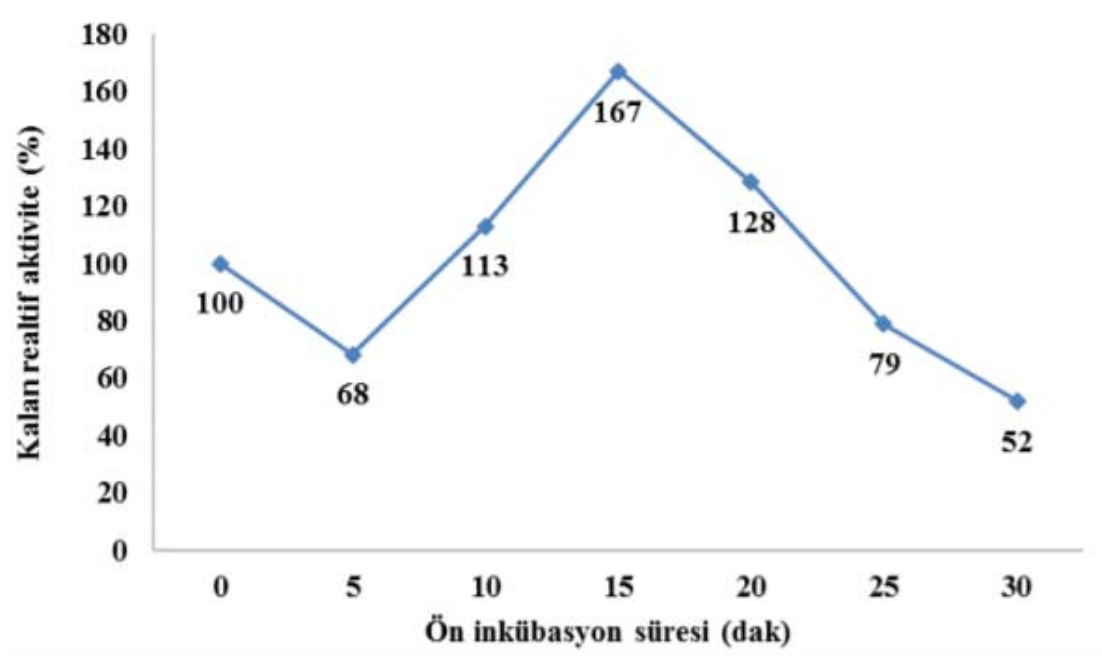

Şekil 6. Hücre dışı ksilanazın termal stabilitesi

B34 suşundan kısmi olarak saflaştırılan ksilanaz enziminin moleküler ağırlığı \%12’lik homojen SDS-PAGE sistemi kullanılarak belirlenmiş olup enzime ilişkin protein bandı Şekil 7'de 
gösterilmiştir. Ksilanaz enzimine ait $38.75 \mathrm{kDa}$ moleküler ağırlığında tek protein bandı elde edilmiştir. B. licheniformis SC'den saflaştırılan ksilanazın ortalama moleküler ağırlığ $24.6 \mathrm{kDa}$ olarak ortaya konmuştur (Chaturvedi ve Khurana, 2016). Pithadiya ve Thakkar (2016), B. circulans'dan saflaştırılan hücre dışı ksilanazın ortalama moleküler ağırlığını 20 kDa; Kapilan (2015), B. subtilis BS166 suşundan elde edilen enzimin moleküler ağırlığını 66.42 kDa; Shrinivas ve arkadaşları. (2010), Bacillus sp. JB 99'dan saflaştırılan termostabil alkalin ksilanazın moleküler ağırlığı 20 kDa olarak rapor etmişlerdir. Roy ve Rowshanul (2009) ise B. cereus'dan saflaştırılan enzime ait $32 \mathrm{kDa}$ ağırlığında tek protein bandı rapor etmişlerdir.
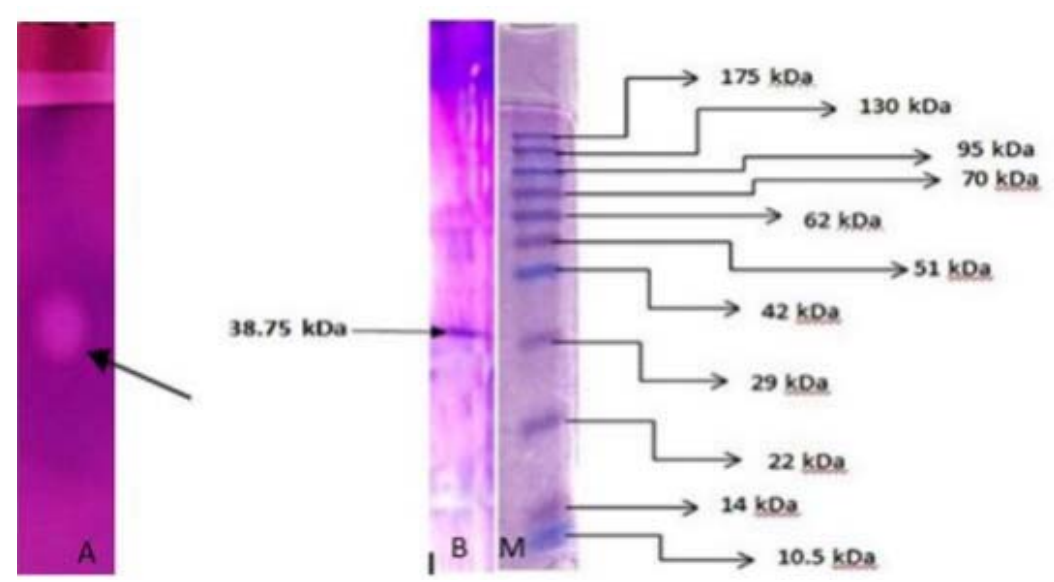

Şekil 7. Ksilanaza ait SDS-PAGE bulguları (A: Ksilanazın SDS-PAGE'de zimogramı, B: Ham ksilanaz preparatının SDS-PAGE'i ve M: Protein marker)

\section{Sonuçlar ve Öneriler}

Yem endüstrisinde $70-90^{\circ} \mathrm{C}$ 'de gerçekleştirilen pellet oluşturma (Yeğin ve Büyükkilleci, 2015) işlemleri sırasında termostabil NOP yıkıcı enzim ihtiyacı, çalışmamızda elde ettiğimiz termostabil ksilanazın yem endüstrisinde potansiyel uygulanabilirliğini ifade etmektedir. Ekonomisi büyük ölçüde hayvancılığa bağlı ülkemiz için, çalışmamızda elde ettiğimiz ksilanaz düşük değerli tarımsal yan ürünlerin hayvan yemi olarak kullanılabilirliğine olanak sağlayabilecektir. İleriki çalışmalarımızda, B34 suşundan elde edilen hücre dışı ksilanaz enziminin başta yem endüstrisi olmak üzere, çeşitli endüstriyel biyo-proseslerde kullanılabilirliğini arttıracak, düşük değerli tarımsal yan ürünleri substrat olarak kullanıp üretim ortamının optimizasyon çalışmalarına yön verilecektir.

\section{Teşekkür}

Bu yüksek lisans tezinin kimyasal desteği "Bacillus spp. suşlarından ksilanaz enziminin kısmi saflaştırması ve plasmid profillerinin belirlenmesi" konulu proje kapsamında TÜBİTAK BIDEB 
2209/A Üniversite Öğrencileri Yurt İçi Araştırma Projeleri Destek Programı tarafından sağlanmıştır.

Bu sebeple TÜBİTAK'a desteklerinden dolayı teşekkür ederim.

\section{Kaynaklar}

Abo-State, M. A. M., Fadel, M., Abdellah, E. M., and Ghaly, M. F., (2013). Studying the stability of cellulases and xylanase produced by thermophilic and alkaliphilic bacterial strains 1solated from agricultural wastes. American-Eurasian Jouranl of Agriculture and Environmental Sciences, 13(11), 1568-1575.

Aygan, A. (2008). Haloalkalofil Bacillus spp. izolasyonu, amilaz, selülaz ve ksilanaz enzimlerinin üretimi, karakterizasyonu ve biyoteknolojik uygulamalarda kullanılabilirliği. Doktora Tezi, Çukurova Üniversitesi, Fen Bililmleri Enstitüsü, Adana.

Butt, M. S., Nadeem, M. T., Ahmad, Z., and Sultan, M. T. (2008). Xylanases and their applications in baking industry. National Institute of Food Science and Technology, 46(1) 22-31.

Chakdar, H., Kumar, M., Pandiyan, K., Singh, A., Nanjappan, K., Kashyap1, P. L., and Srivastava, A.K, (2016). Bacterial xylanases: biology to biotechnology. 3 Biotech, 6(2), 150.

Chaturvedi, S., and Spaul Khurana, S. M. (2016). Partial purification and characterization of cellulase-free xylanase production from Bacillus licheniformis. International Journal of Pharma and Bio Sciences, 7(4), 144-149.

Cordeiro, C. A. M., Martins, M. L. L., Luciano, A. B., and Silva, R. F. (2002). Production and properties of xylanase from thermophilic Bacillus spp. Brazilian Archives of Biology and Technology an International Journal, 45(4), 413-418.

Duarte, M. C. T., Pellegrino, A. C. A., Portugal, E. P, Ponezi, A. N., and Franco, T. T. (2000). Characterization of alkaline xylanases from Bacillus pumilus. M.C.T. Brazilian Journal of Microbiology, 31, 90-94.

Hiremath, K. S., and Patil, C. S. (2011). Isolation, production and characterization of alkalo thermostable xylanase from newly isolated Bacillus spp. International Journal of Biotechnology Applications, 3(1), 48-51.

Irfan, M., Asghar, U., Nadeem, M., Nelofer, R., and Syed, Q. (2016). Optimization of process parameters for xylanase production by Bacillus spp. in submerged fermentation. Journal of Radiation Research and Applied Sciences, 9, 139-147.

İnce, E. (2006). Ksilanaz üreten ekstrem termofil anaerobik bakterilerin izolasyonlart ve enzimlerinin özelliklerinin belirlenmesi. Yüksek Lisans Tezi, Ankara Üniversitesi Fen Bilimleri Enstitüsü, Ankara.

Kalim, B., and Nazish, M. A. (2016). Optimization of fermentation media and growth conditions for microbial xylanase production. 3 Biotech, 6(2), 122.

Kamble, R. D., and Jadhav, A. R. (2012). Xylanase production under solid-state and submerged fermentation conditions by bacterial strains. African Journal of Microbiology Research, 6, 4292-4297.

Kapilan, R. (2015). Purification of xylanase from Bacillus subtilis Bs166. Journal of Science, 5(7), 2277-3290.

Kırkpınar, F., ve Açıkgöz, Z. (2003). Kanatlı hayvanlarda nişasta tabiatında olmayan polisakkaritlerin sindirim sistemi mikroflorası üzerine etkileri. Hayvansal Üretim, 44(2), 20-28.

Laemmli, U.K. (1970). Cleavage of structural proteins during the assembly of bacteriophage T4. Nature, 227, 680-685.

Lowry, O. H., Rosebrough, N.J., Farr, A. L., and Randall, R. J. (1951). Protein measurement with the Folin phenol reagent. Journal of Biological Chemistry, 193, 265-275.

Mahilrajan, S., Balakumar, S., and Arasaratnam, V. (2012). Effect of xylan on xylanase production by Bacillus pumilus under submerged fermentation. Ving. Journal of Science, 11(1), 12-18.

Mittal, A., Nagar, S., Simran Jot Kaur, K., and Gupta, V. (2012). Isolation, purification and characterization of alkali and thermo stable xylanase from Bacillus spp. International Journal of Research and Development in Pharmacy and Life Sciences, 1(2), 63-68.

Motta, F. L., Andrade, C. C. P., and Santana, M. H. A. (2013). A Review of xylanase production by the fermentation of xylan: classification, characterization and applications. In: Chandel A.K., da Silva S.S. (Eds) sustainable degradation of lignocellulosic biomass -techniques, applications and commercialization, InTech, Croatia. 251-266.

Paes, G., and O'Donohue, M.J. (2006). Engineering increased thermostability in the thermostable GH-11 xylanase from Thermobacillus xylanilyticus. Journal of Biotechnology, 125, 338-350. 
Pithadiya, D., Nandha, D., and Thakkar, A. (2016). Partial purification and optimization of xylanase from Bacillus circulans. Scholars Research Library, 8(2), 1-10.

Roy, N., and Rowshanul, M. (2009). Isolation and characterization of xylanase producing strain of Bacillus cereus from soil. Iranian Journal of Microbiologgy, 2, 49-53.

Sargın, S., ve Öngen, G. (2003). Kanatlı yemi katkısı olarak kullanılan ksilanaz enziminin katı kültür fermantasyon yöntemi ile üretiminde ölçek büyütme çalışmaları, Ege Üniversitesi Ziraat Fakültesi Dergisi, 40(3), 145-152.

Sharma, S. C. D., Shovon, M. S., Asaduzzaman, A. K. M., Sarowar Jahan, M. G.,Yeasmin, T., and Roy, N. (2011). Optimization of alkali-thermostable and cellulase-free xylanase production from Bacillus spp. Journal of Biosciences, 19, 7-14..

Shrinivas, D., Savitha, G., and Raviranjan, K. (2010). A highly thermostable alkaline cellulase-free xylanase from thermoalkalophilic Bacillus spp. JB 99 suitable for paper and pulp industry: Purification and characterization. Applied Biochemistry and Biotechnology, 162, 2049-2057.

Sarı, B. (2016). Rize ayder kaplıcalarından alınan su örneklerinden termofilik bakterilerin izolasyonu, identifikasyonu, ksilanaz enziminin Geobacillus galactosidasius BS61 bakterisinden saflaştırtlması ve karakterizasyonu. Yüksek Lisans Tezi, Atatürk Üniversitesi Fen Bilimleri Enstitüsü, Erzurum.

Silva, L. G., Trugo, L. C., Terzi, S. C., and Couri, S. (2005). Low phytate lupin flour based biomass obtained by fermentation with a mutant of Aspergillus niger. Process Biochemistry, 40, 951-954.

Tamariz-Angeles, C., Olivera-Gonzales, P., Villena, G. K., and Gutierrez-Correa, M. (2014). Isolation and identification of cellulolytic and xylanolytic bacteria from huancarhuaz hot spring, Peru. Annual Research \& Review in Biology, 4(19), 2920-2930.

Yeğin, S., ve Büyükkilleci, A.O. (2015). Mikrobiyal ksilanazlar ve gıda endüstrisinde kullanım alanları. Akademik Glda, 13(4), 317-326.

Yeoman, C.J., Han, Y., Dodd, D., Schroeder, C.M., Mackie, R.L., and Cann, I.K.O (2010). Thermostable enzymes as biocatalysts in the biofuel industry. Advances of Applied Microbiology, 70: 1-55.

Zambare, V., Zambare, A., Muthukumarappan, K., and Christopher, L. P. (2011). Biochemical characterization of thermophilic lignocellulose degrading enzymes and their potential for biomass bioprocessing. International Journal of Energy and Environment, 2(1), 99-112. 